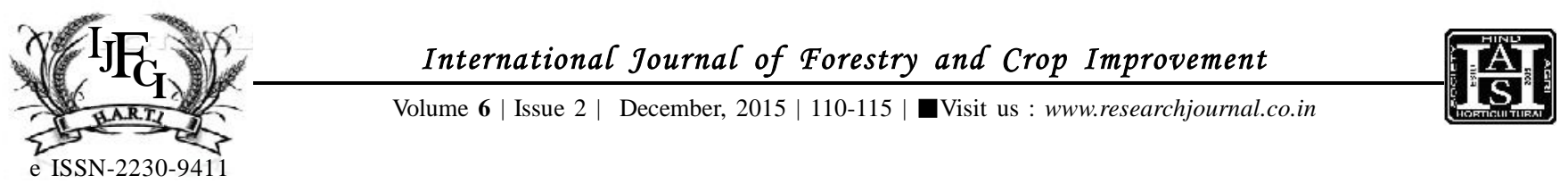

\title{
Genetic variability and character association for fodder yield and its related traits in pearl millet over locations under rainfed conditions of Gujarat
}

\author{
K.K. DHEDHI, V.V. ANSODARIYA, N.N. CHAUDHARI, J. M. SANGHANI AND J.S. SORATHIYA
}

\begin{abstract}
A set of 23 genotypes of fodder pearl millet were studied for genetic variability, heritability, genetic advance and character association of green fodder yield and its components at Jamnagar and Dhari under rainfed condition of Gujarat during Kharif-2014. The analysis of variance revealed highly significant differences among the genotypes for all the seven characters studied. All the genotypes showed considerable amount of variation in their mean performance with respect to the characters studied, indicates presence of sufficient variability and scope for further selection and breeding superior and desirable genotypes. The variability analysis revealed that harvest index, grain yield, dry fodder yield and green fodder yield had high magnitude of phenotypic range, genotypic co-efficient of variation, phenotypic co-efficient of variation, heritability and genetic advance expressed as percentage of mean thereby suggesting the importance of additive gene action. Hence, these characters can be improved through simple selection process. Green fodder yield had significant positive correlation with days to 50 per cent flowering, days to maturity and dry fodder yield at both genotypic and phenotypic levels indicating any increase in these traits will increase the green fodder yield.
\end{abstract}

KEY WORDS : Pearl millet, Variability, Heritability, Correlation co-efficient, Green fodder yield

How TO CITE THIS ARTICLE : Dhedhi K.K., Ansodariya, V.V., Chaudhari, N.N., Sanghani, J.M. and Sorathiya, J.S. (2015). Genetic variability and character association for fodder yield and its related traits in pearl millet over locations under rainfed conditions of Gujarat. Internat. J. Forestry \& Crop Improv., 6 (2) : 110-115.

ArTiCle Chronical : Received : 31.07.2015; Revised : 11.11.2015; Accepted : 23.11.2015

Address of the Correspondence : K.K. DHEDHI, Pearl Millet Research Station (J.A.U.) JAMNAGAR (GUJARAT) INDIA

Email: kkdhedhi@rediffmail.com

V.V. ANSODARIYA, Grassland Research Station (J.A.U.) DHARI (GUJARAT) INDIA

Address of the Coopted Authors : N.N. CHAUDHARI, J.M. SANGHANI AND J.S. SORATHIYA, Pearl Millet Research Station, Junagadh Agricultural University, JAMNAGAR (GUJARAT) INDIA 